\section{d) mpI} MIGRATION POLICY

\section{SUMMARY}

Countries of origin can play a major role in protecting their migrant workers abroad. A government-operated welfare fund that migrants and/or their employers finance offers a potentially efficient and feasible solution to sharing the cost of protection. An analysis of the world's largest migrant welfare fund, the Philippines' Overseas Workers Welfare Administration (OWWA), shows that protection of migrant workers can be institutionalized through three elements: (I) a mechanism for repatriation, (2) provision of insurance and loans, and (3) education and training.

However, countries of origin must overcome several limitations if they want to realize these benefits. The Philippine case highlights the importance of tailoring services to the immediate or core needs of overseas workers without overextending the government's capacity, as well as of creating meaningful partnerships with members of the civil society and the private sector. Also critical to successful operation is a strong state capacity that allows for the representation and meaningful participation of migrant workers; political, administrative, and financial transparency and accountability; and the effective use of government employees. Further, since protection of migrant workers is a transnational issue that requires transnational solutions, partnerships across borders are also necessary. Destination countries should be active partners and should complement the offerings of welfare funds.

Protecting overseas workers will gain more attention as temporary migration continues to grow worldwide. A membership-driven welfare fund like OWWA can benefit migrants in a number of ways. Once its limitations are addressed, this Insight shows that OWWA can be a useful template for many developing countries as they face the mounting challenges of protecting workers abroad.

\section{Protecting Overseas Workers:}

\section{Lessons and Cautions from the Philippines}

\author{
Dovelyn Rannveig Agunias \\ Migration Policy Institute
}

\author{
Neil G. Ruiz \\ The Brookings Institution
}

\section{Introduction}

International labor mobility is increasing, as a matter of policy and a matter of fact. Yet, countries of origin and destination have reached little consensus on how best to mitigate the social costs of a more integrated global labor market. As proposals for temporary worker programs in developed countries spark political debates on immigration reform, national governments and international organizations have been grappling with questions about the welfare and protection of migrants. Reports of maltreatment and exploitation of foreign workers come from all migrantreceiving countries, from the Middle East and Singapore to more traditional migrant-receiving countries like the United States. How can governments ensure migrants are protected while working abroad?

This Insight examines one method of tackling this everincreasing problem from the perspective of the Philippines, a traditional migrant-sending country. ${ }^{1}$ It gives an overview 
of the welfare services that the Philippine government provides to its citizens who are temporary overseas workers rather than permanent emigrants. It is based on interviews with several high-level government officials and migrants' organizations, as well as on an analysis of several data sources on the welfare and protection services available to overseas workers. Although not a detailed performance evaluation of Philippine programs, the paper provides an understanding of the policies, functions, and challenges that the Philippine government addresses through a unique government institution, the Overseas Workers Welfare Administration (OWWA), to protect its overseas workers abroad.

Countries of origin can play a major role in protecting their migrant workers abroad through an institutionalized welfare fund, but policymakers need to
Countries of origin can play a major role in protecting their migrant workers abroad through an institutionalized welfare fund. exercise caution given the limitations governments in origin countries face. The Philippine experience highlights the importance of developing state capacity to effectively deliver services, ensuring accountability to and representation of migrant workers, and creating meaningful partnerships within as well as beyond a state's borders.

\section{Emigration from the Philippines}

For more than three decades, the Philippine government has adopted a deliberate policy of labor export. High unemployment rates, especially among the highly educated, and political instability are the main push factors. ${ }^{2}$ With increasing pull factors from major industrial countries that are suffering from labor shortages, the Philippine government's labor-export system allows and encourages Filipinos to benefit from these opportunities.

As of December 2006, Philippine government estimates placed the stock of all overseas Filipinos, including temporary workers, permanent emigrants, and irregular migrants, at 8.2 million, which amounts to almost 25 percent of the total labor force and 9 percent of the country's total population. ${ }^{3}$ Today, the Philippines is the largest organized laborexporting country in the world. Although a substantial proportion of the Filipinos abroad are permanent emigrants (most of whom settle in the Americas), the majority of overseas Filipinos are contract or temporary workers, officially called overseas Filipino workers or OFWs. ${ }^{4}$ Figure 1 provides an overview of the astonishing growth of land-based and seabased OFWs from 1974, when the government initiated its labor-export policy, to 2006. Almost two-thirds of these OFWs originated from the countryside ${ }^{5}$ and almost half have college degrees. ${ }^{6}$

The number of OFWs has increased almost 25 -fold over the past 20 years, with nearly 1.2 million registered deployments to over 190 countries in 2006 alone. ${ }^{7}$ Most OFWs go to the Middle East and East Asia, as highlighted in Figure 2, but the numbers have recently been increasing in Europe as well. Seafarers make up a significant proportion of 
Figure I. Deployed Overseas Filipino Workers, 1975 to 2006 (in thousands)

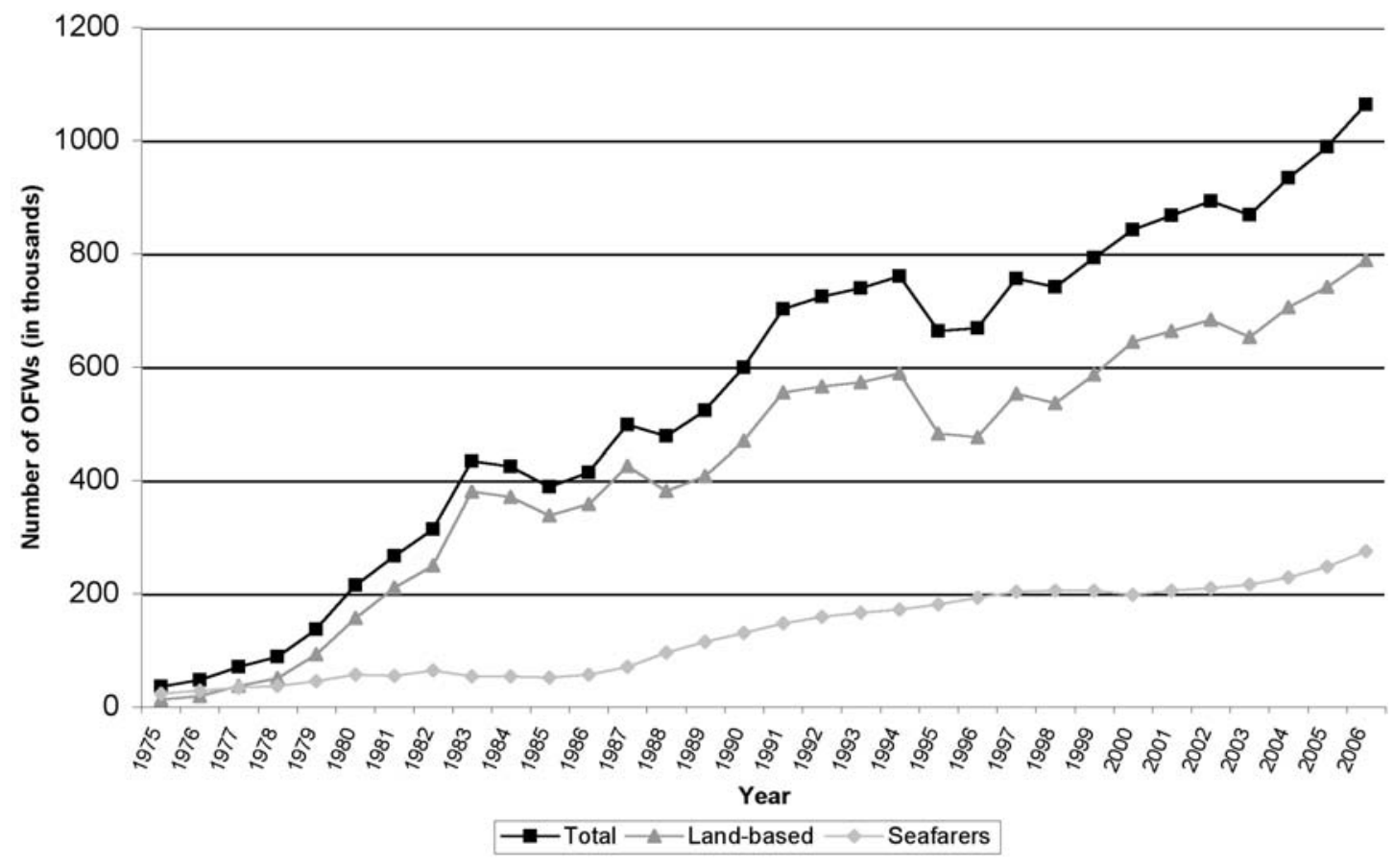

Source: Philippine Statistical Yearbooks, 1984 to 2006.

OFWs with almost a quarter of a million deployed annually, and they compose 30 percent of all seafarers in the world.

Celebrated nationally as "modern-day heroes," the remittances from this huge Diaspora have emerged as a major source of the country's foreign exchange inflows, averaging 8.9 percent of gross national product (GNP) over the last five years and over 23 percent of export earnings. ${ }^{8}$ According to the Central Bank of the Philippines, remittances in 2006 reached US $\$ 12.8$ billion and are projected to approach the US $\$ 15$ billion mark in 2007. ${ }^{9}$

Although government policy initially focused on exporting professionals, OFW occupations abroad have diversified over time to include factory workers, construction workers, and service workers, such as care givers and domestic helpers (see Figure 3 and Appendix 1). Professionals are still the third-largest group of OFWs; that category includes nurses and engineers. 
Note:

To see the Maps more clearly, please zoom in on the screen by clicking the Zoom In (+) button in the toolbar.
Figure 2. Deployed Overseas Filipino Workers by Destination, Annual Average, 2002 to 2006
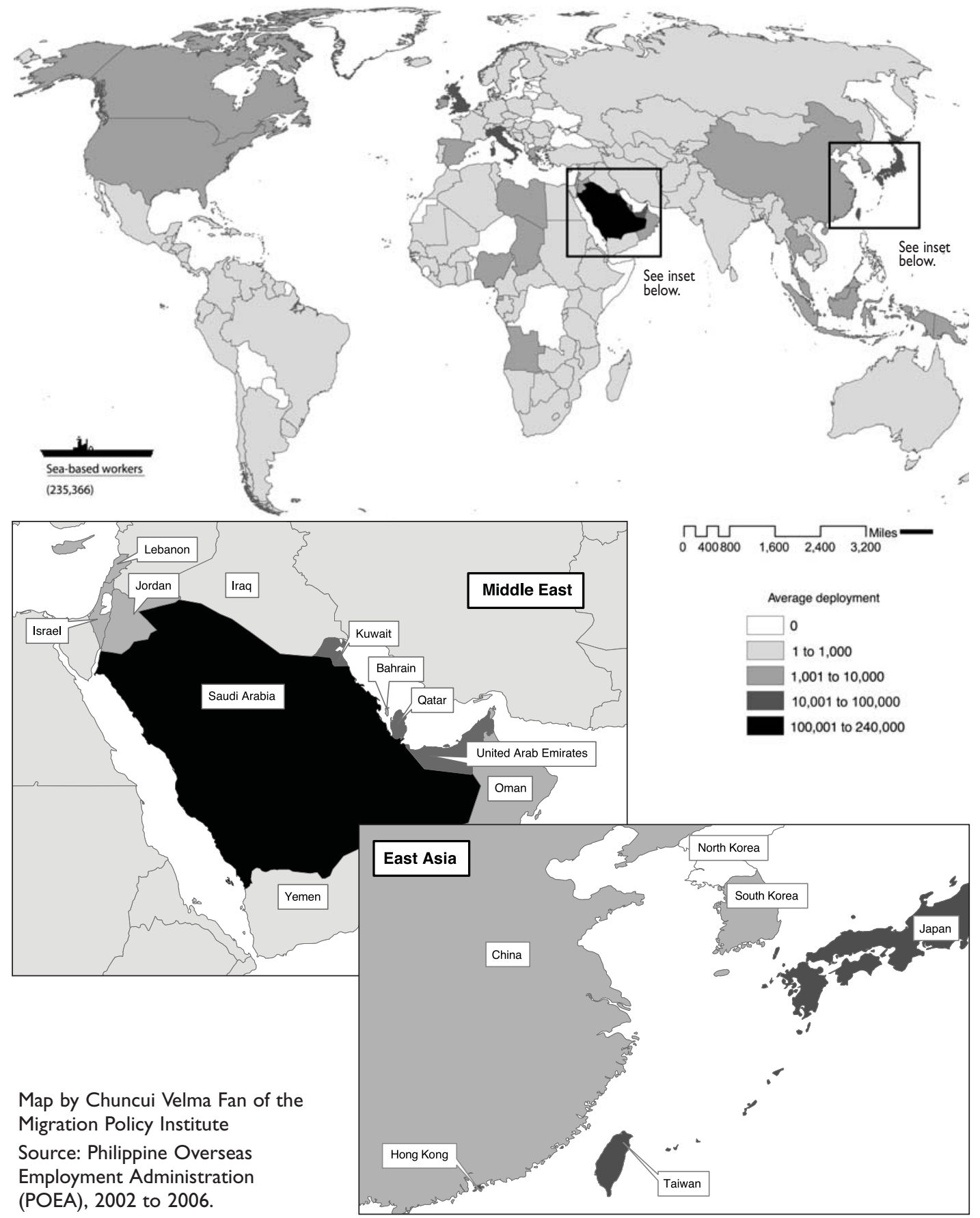


\section{Insight}

Figure 3. Overseas Filipino Workers by Occupational Type Abroad

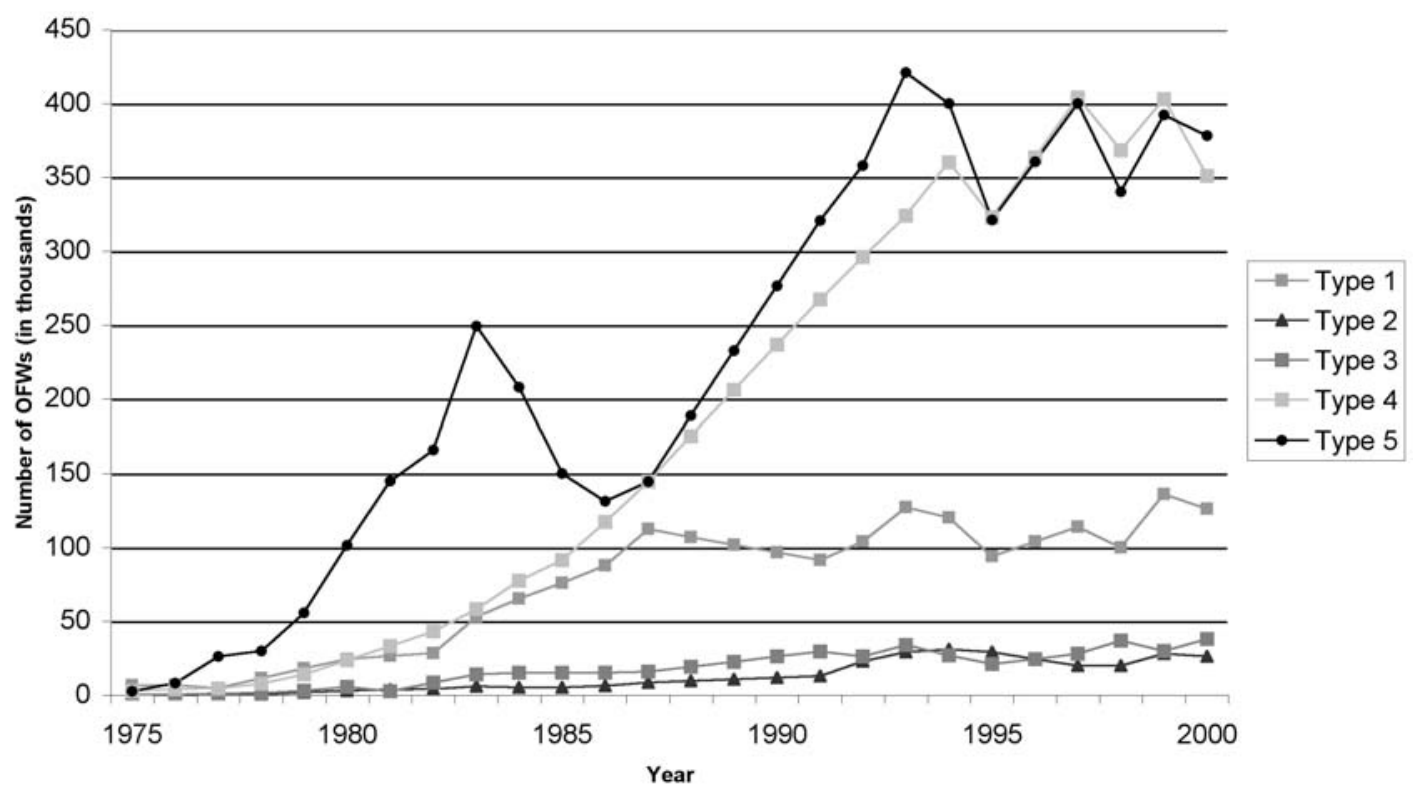

Note: Type I includes professional, technical, and related workers (as well as entertainers). Type 2 includes managerial, executive, and administrative workers; sales workers; and agricultural, husbandry, and forestry workers, and fishermen.

Type 3 includes clerical workers.

Type 4 includes service workers.

Type 5 includes production process workers, transport equipment operators, and laborers. Please see Appendix I for more detailed information.

Source: Philippine Statistical Yearbooks, various years as cited in Neil G. Ruiz, "Made for Export: Labor Migration, State Power, and Higher Education in a Developing Society," Ph.D. dissertation, Massachusetts Institute of Technology, 2007.

A shift in the international demand for

Philippine labor took place in the 1980s, indicated by a decline in the relative share of workers in production processes and related occupations, and an increase in the international demand for service workers. In the Philippines, this led to more women going abroad, mainly to work as domestic helpers in Hong Kong, Singapore, and the Middle East, and as entertainers in Japan.

Studies from the early 1980s showed that men originally composed an overwhelming majority of OFWs. By 1987, 47 percent of all deployed land-based workers were women. This proportion rose to almost 50 percent in 
1994, a trend that continues well into the current decade. As of 2006, 60 percent of new hires were women. ${ }^{10}$

\section{The Institutionalization of Labor Export}

In 1974, President Ferdinand Marcos issued a presidential decree creating three government institutions within the Ministry of Labor to facilitate the export of workers: the Overseas Employment Development Board (OEDB), the Bureau of Employment Services (BES), and the National Seamen Board (NSB). As overseas employment became more significant, the Philippine government was not able to meet the increasing demands for processing and recruiting workers. The growing need for more private-sector participation led the government to merge these three agencies into the Philippine Overseas Employment Administration (POEA) in 1982. POEA's sole purpose is to manage the recruitment and deployment of Filipinos for overseas contract work abroad.

Through POEA, the government encourages the "responsible" participation of the private sector. POEA licenses all private recruitment agencies and plays a major

POEA ensures that private recruitment agencies and employers in destination countries do not cheat potential and current overseas workers. role as "regulator" by informing potential overseas workers of agencies that have issued false contracts or have not complied with rules during the deployment process. In other words, POEA ensures that private recruitment agencies and employers in destination countries do not cheat potential and current overseas workers.

The other reason for restructuring government institutions in 1982 was to mitigate the risks involved in migration, such as exploitation and abuse. A 1977 White Paper by the Ministry of Labor and Employment recommended that the government focus on protecting and promoting the welfare and rights of OFWs rather than focus solely on recruiting and placing them. ${ }^{11}$

In response, the government created the Welfare Fund Administration (WFA) in 1980, which later became the Overseas Workers Welfare Administration (OWWA), an independent financial agency that manages the welfare fund of overseas workers and provides services to its contributing members like insurance and loans.

OWWA is essentially a single trust fund pooled from the mandatory US $\$ 25$ membership contributions of foreign employers, landbased and sea-based workers, investment and interest income on these funds, and income from other sources. Categorized as a quasigovernmental entity, it is entirely self-funded and receives no budget allocation from the national government.

\section{The Need for a Welfare Fund}

As a result of state involvement and an increase in Filipino emigration, major political issues arose around reports of the maltreatment, illegal recruitment, and even 
deaths of OFWs. Between 1987 and 1991, a total of 23 Senate bills and 32 House bills were filed in the Philippine Congress in an attempt to investigate several mysterious OFW deaths.

In addition, the government has needed to conduct large-scale repatriations from the Middle East due to political events in the region. During the 1991 Gulf War, the government brought home about 30,000 Filipinos from Iraq and Kuwait. The repatriation highlighted problems in coordination, lack of reliable data on the Filipinos in the region, and the inadequate number of government personnel abroad. The repatriation also strained relations between government officials and the workers they were trying to repatriate. $^{12}$

These developments reached a defining moment in 1995. Flor Contemplacion, a Filipina domestic worker in Singapore, was charged with murdering another domestic worker, Delia Maga, and the child of Maga's employer. After being drugged and administered electric shocks, Contemplacion, who spoke little English, was reportedly coerced into a confession without a lawyer present. She was later put to death despite the Philippine president's direct appeal to the government of Singapore. ${ }^{13}$

This incident sparked protests in the Philippines that challenged the state's labor-export policy. A grenade exploded outside of the Singapore Airlines office in Metro Manila following the news of Contemplacion's death, ${ }^{14}$ and mass demon- strations also took place at the Embassy of Singapore in Manila and at the departments of Foreign Affairs (DFA) and Labor and Employment (DOLE). The Philippines downgraded its diplomatic relations with Singapore, the secretaries of DFA and DOLE resigned, and the deployment of domestic helpers to Singapore was temporarily halted. ${ }^{15}$

The perceived injustice surrounding Contemplacion's death heightened the sentiments of an increasingly uneasy society after more than two decades of large-scale temporary emigration. A 42-year-old mother of four and sole provider for her family, Contemplacion came to symbolize the sacrifices of Filipino migrants - the "modernday heroes" willing to risk even death to provide for their families back home. As Joaquin Gonzales, an expert on Philippine studies, noted in his book, Philippine Labour Migration: Critical Dimensions of Public Policy, Contemplacion's death "heightened Contemplacion came to symbolize the sacrifices of Filipino migrants the "modern-day heroes" willing to risk even death to provide for their families back home. long-standing debates in the Philippines and exposed the lack of adequate government attention to the plight of Filipino overseas contract workers [OCWs], not just in Singapore but in all the labor-receiving countries."16

Indeed, Contemplacion's case was not an exception. According to DOLE, between 1996 and 2001, the bodies of about 1,224 
OFWs were repatriated. ${ }^{17}$ All of these OFWs were said to have died of "unknown or mysterious circumstances." Congressional hearings on this issue, held in 2001, revealed that many of the bodies, particularly those of domestic workers employed in Taiwan and Hong Kong, "bore bruises and deep cuts." In some cases, autopsy examinations discovered that internal organs were missing, possibly sold for transplants to unknown beneficiaries. $^{18}$

Other negative reports about treatment of OFWs also spread throughout the Philippine media. Illegal recruitment for positions as prostitutes or "comfort women" became another politicized issue. Another highly publicized case was that of Maricris Sioson, a performing artist who died in Japan in
1991 under suspicious circumstances. ${ }^{19}$ In Hong Kong, Japan, Taiwan, and Singapore, many Filipina women were and are still brought to work as "hostesses" at bars. Philippine government statistics from 1994 show that women are more likely to be victims due to the nature of their work (see Table 1).

\section{The 1995 "Magna Carta"}

These events in the early 1990s resulted in the most significant reorganization to date of the Philippines' labor-export policy, namely the Migrant Workers and Overseas Filipino Act of 1995. The so-called Magna Carta responded directly to the Contemplacion case. The law called for government to promote the welfare of migrant workers and place their protection above all else. It states:

Table I. Number of Welfare Cases, January to September 1994

\begin{tabular}{|l|c|c|c|c|}
\hline Nature & Total & Male & Female & Female/male ratio \\
\hline Overall (number) & 9,368 & 3,021 & 6,347 & 2.1 \\
\hline Overall (percent) & 100 & 32 & 68 & \\
\hline Maltreatment & 1,419 & 546 & 873 & 1.6 \\
\hline Delayed or nonpayment of salaries & 1,272 & 565 & 707 & 1.2 \\
\hline Contract violations & 1,373 & 691 & 682 & 0.9 \\
\hline Physical abuse & 187 & 6 & 181 & 30.0 \\
\hline Rape and sexual abuse & 15 & 0 & 15 & N/A \\
\hline Sexual harassment & 330 & 0 & 330 & N/A \\
\hline Health problems & 42 & 13 & 29 & 2.2 \\
\hline Mental illness & 6 & 0 & 6 & N/A \\
\hline Other & 3,769 & 694 & 3,075 & 4.4 \\
\hline Source: Overseas Workers Welfare Administration, as cited in "Filipino Women Migrants: A Statistical \\
Factbook," National Commission on the Role of Filipino Women and the Asian Development Bank.
\end{tabular}


While recognizing the significant contribution of Filipino migrant workers to the national economy through their foreign exchange remittances, the State does not promote overseas employment as a means to sustain economic growth and achieve national development. The existence of the overseas employment program rests solel $^{20}$ on the assurance that the dignity and fundamental human rights and freedoms of the Filipino citizen shall not, at any time, be compromised or violated.

The Philippine government put in place many programs to protect and represent Filipino migrants. The Magna Carta created an Office of the Legal Assistant for Migrant Workers Affairs (OLAMWA) within the Department of Foreign Affairs (DFA) to take responsibility "for the provision and coordination of all legal assistance services to be provided to Filipino migrant workers as well as overseas Filipinos in distress." ${ }^{21}$

Nevertheless, OWWA remains the main agency for protecting Filipinos while abroad due to its much larger scope of responsibilities, which extend beyond the provision of legal assistance. ${ }^{22}$

\section{How OWWA Is Organized}

OWWA is an international operation organized by a migrant-sending government. This entails a complex organizational structure that includes a board of trustees, a secretariat, and regional and international offices.

\section{The Board of Trustees}

OWWA's board of trustees is a tripartite body with the DOLE secretary as chair and 12 members representing government, management, and OFWs. The president of the Philippines appoints all board members. The board is broadly representative of a cross-section of government agencies, including the Departments of Foreign Affairs, Finance, and Budget. OFWs are allotted sea-based, land-based, and women's sector representatives (see Figure 4). An overwhelming majority of board members are not OWWA members, a major source of civil society and OFW criticism.

The board plans and implements policies and programs, crafts the rules and regulations, oversees fund sources, and creates yearly appropriations for the Secretariat, OWWA's administrative arm. ${ }^{23}$ Unlike other Philippine government agencies that administer trust funds, OWWA has no charter. This setup allows for more flexibility but may also allow the board to exercise blanket and unregulated authority. As a permanent government agency, changes to OWWA's operations can only be made through legislation.

\section{The OWWA Secretariat}

The Secretariat, headed by an administrator, manages day-to-day operations in the Philippines and abroad. Of its staff of 580, only about 100 employees are stationed at its main office in Manila. The rest are stationed at regional offices within the Philippines (about 300 employees) or based in countries 
Figure 4. OWWA Board of Trustees

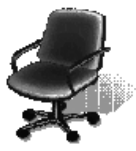

DOLE secretary and chairman

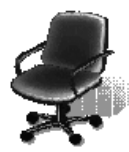

OWWA

administrator and vice chairman

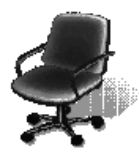

DOLE

undersecretary

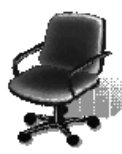

DFA

undersecretary

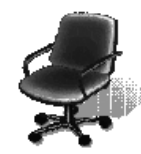

DBM assistant secretary

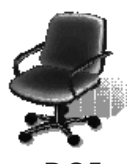

DOF

undersecretary

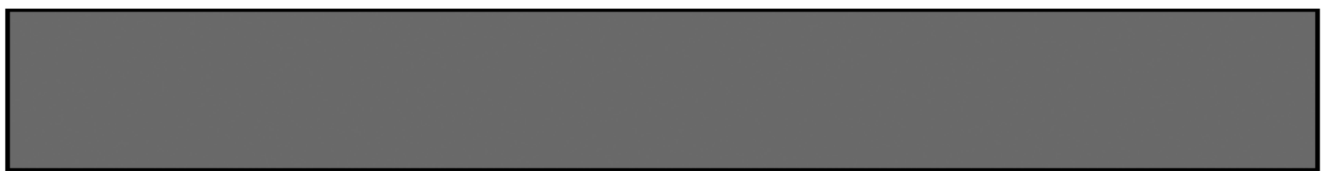

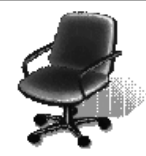

POEA administrator

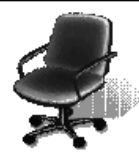

Labor sector representative

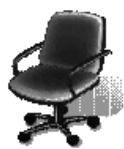

Management sector representative

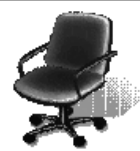

OFW sea-based representative

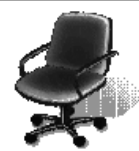

OFW land-based representative

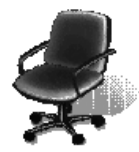

OFW women's sector representative

Source: Overseas Workers Welfare Administration.

with particularly large numbers of temporary workers (about 180 employees). ${ }^{24}$ In 2006 , 28 welfare officers were assigned to 16 countries, with more than half of them placed in the Middle East, including nine in Saudi Arabia alone (see Figure 5). The OWWA administrator recommends welfare officers, whom the DOLE secretary nominates and whom the president of the Philippines appoints. The welfare officers abroad work together with the labor attachés and the ambassadors or consuls-general to assist Filipino migrant workers (see Figure 6). They are usually attached to Philippine embassies and consulates. Indeed, the government considers OWWA staff abroad to be part of its unified team in that country, with the ambassador as the leader. ${ }^{25}$

\section{Membership}

Membership in OWWA, which is mandatory for migrants going abroad through official channels, may be obtained in two ways: by enrollment upon processing of a contract at POEA or by voluntary registration of a would-be member at a job site overseas. Membership is valid until the OFW's employment contract expires. For voluntary members who register at a job site, membership does not exceed two years. ${ }^{26}$

Ideally, the employer and/or agency pays the \$US25 membership fee, a practice that some critics say rarely happens in reality. A 2004 independent field study by the Scalabrini Migration Center, a Manila-based research institute, confirmed that the membership fee 


\section{Insight}

Figure 5. OWWA Welfare Officers by Destination, 2006

Note:

To see the Maps more clearly, please zoom in on the screen by clicking the Zoom In (+) button in the toolbar.
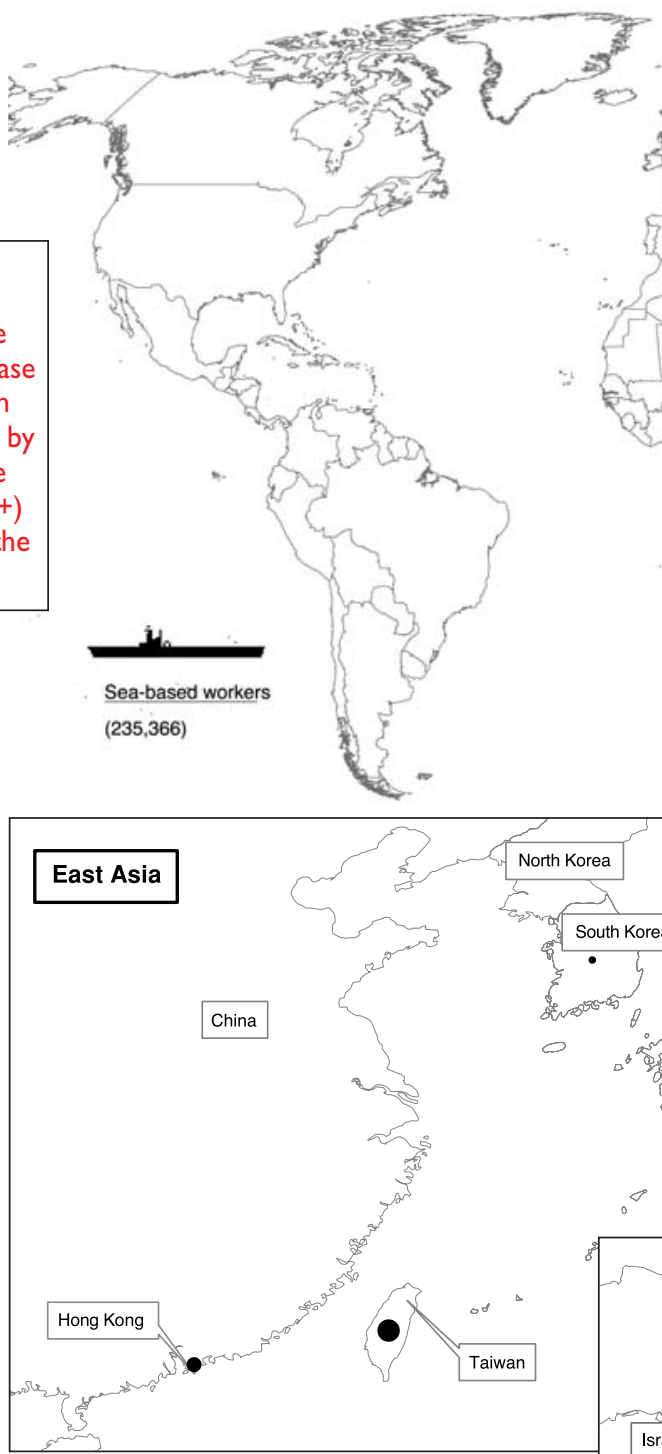

Map by Chuncui Velma Fan of the Migration Policy Institute

Source: Overseas Workers Welfare Administration (OWWA), 2006.

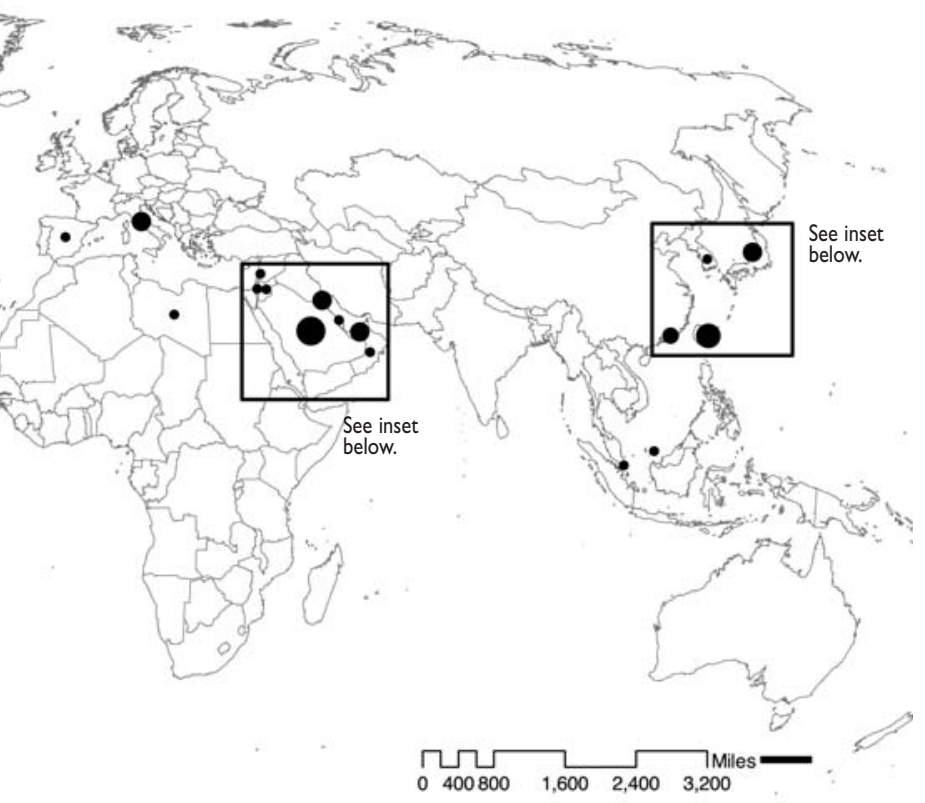

Number of OWWA welfare officers

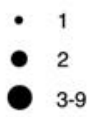

Middle East

Iraq
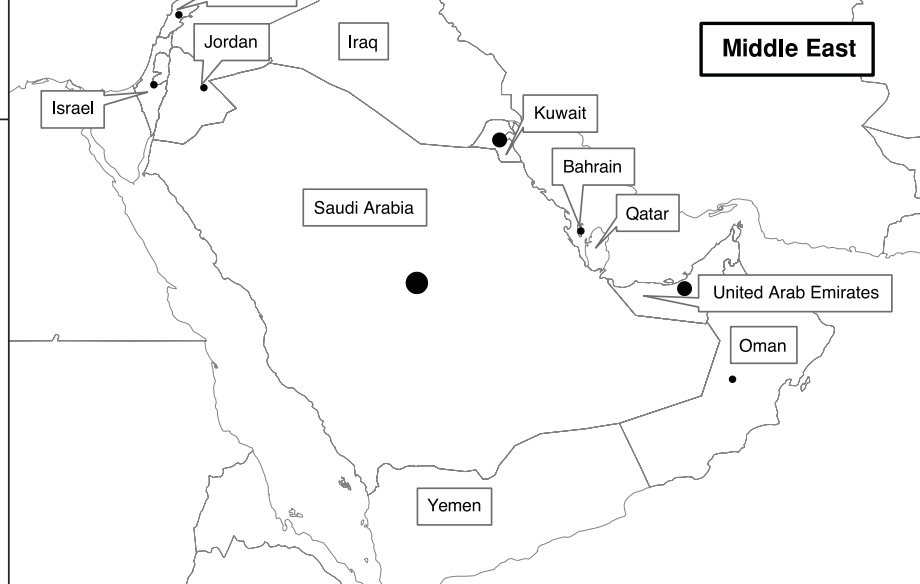
Figure 6. Organizational Chart of OWWA within the Philippine Government

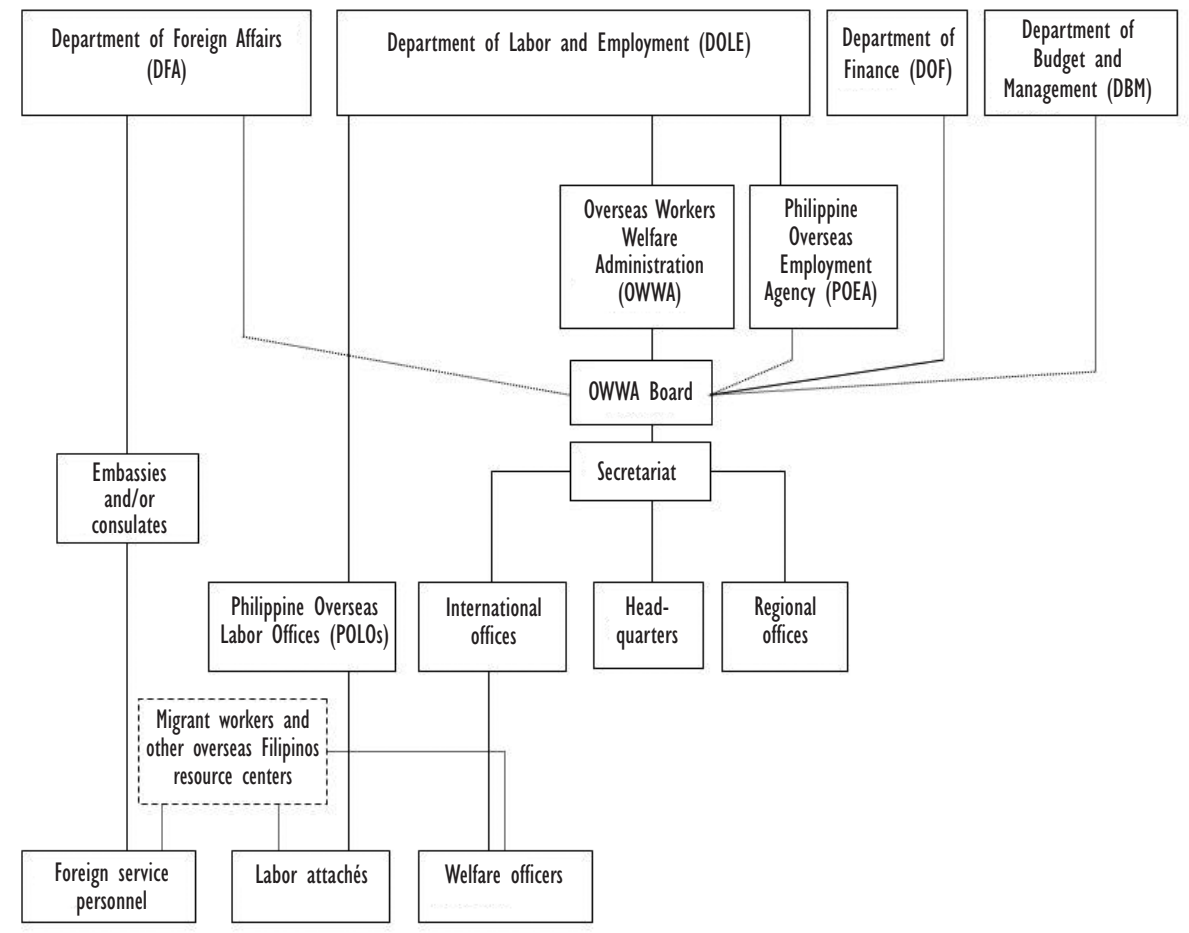

Sources: Overseas Workers Welfare Administration and Department of Labor and Employment.

is "routinely passed onto migrant workers." 27 Although the mandatory nature of membership has been instrumental in shoring up the fund's assets, some migrant organizations are questioning the authority of OWWA to require such payment.

The number of OWWA members has increased through the years, reflecting the general upward trend in OFW emigration. It is important to note that, despite the mandatory membership requirements, a large proportion of temporary workers are not OWWA members. As of May 2007, OWWA had over 1 million members, which represents just 28 percent of the 3.8 million legal temporary workers abroad in 2006, as estimated by the Commission on Overseas Filipinos, another government body. This difference, according to current OWWA Administrator Marianito Roque, is a result of the many OFWs who extended their contracts while overseas but did not renew their OWWA membership. ${ }^{28}$

The reasons for nonrenewal are not clear and warrant a careful study. Some may find mem- 
bership unnecessary since they know the government repatriates $\mathrm{OFW}$ s regardless of membership status. Others may be unsatisfied with the services OWWA provides, and some may simply find renewal a difficult or timeconsuming process.

\section{Juggling Two Tasks: Achieving Fund Stability while Providing Services}

The right balance between achieving fund stability and providing much-needed services to its beneficiaries is central to operating any welfare fund successfully. Looking at OWWA data reveals that the balance has tilted more toward achieving fund stability.

In 2005, OWWA spent only 3 percent of the fund balance on services. This ratio may be interpreted positively or negatively. OWWA may be spending less on services now so more is available for future services to future members. At the same time, however, it may also mean OWWA is simply underinvesting in services.

Amassing funds serves two purposes although these purposes are not explicitly part of OWWA's policy framework. Interviews with current and former OWWA officials confirmed that one goal is to achieve enough of a surplus that the interest income alone will support OWWA's annual operating budget. A second purpose, according to administrator Roque, is to reach 10 billion pesos (US\$200 million), ${ }^{29}$ the amount OWWA would need to repatriate all or most
OFWS from the Middle East in a worst-case scenario; OWWA expects to have the 10 billion pesos by October 2007. Once OWWA surpasses that level, it will be able to spend more on services. ${ }^{30}$

While both goals may make sense, they have compromised OWWA's past and present ability to fund welfare services. Yet, this savefirst-spend-later strategy has been critical to achieving financial stability — a crucial component of OWWA's survival and legitimacy. As will be discussed later in the paper, this strategy is compatible with OWWA's role as a contingency fund for large-scale repatriation should the need arise. Moreover, the accumulation of assets now also appears to be a cautious and perhaps The right balance between achieving fund stability and providing muchneeded services to its beneficiaries is central to operating any welfare fund successfully. an easier strategy given the difficulties in extending services, such as loans and education grants, in an efficient and effective manner.

\section{Protecting Overseas \\ Workers on a Budget}

In the last five years, OWWA's income averaged 1.9 billion pesos (US\$38 million) per year. Membership fees comprise the great majority of this income (73 percent) while the rest is from investments and other income.

According to its most recent audited financial statement, as of December 2005, OWWA had a total investment portfolio of 6.7 billion 
pesos (US\$134 million), 90 percent of which had been entered into an Investment Management Agreement with the Land Bank of the Philippines (LBP) and the Development Bank of the Philippines (DBP). ${ }^{31}$ As investment managers, LBP and DBP are authorized to invest/reinvest funds in government securities, such as treasury bills and bonds, the servicing and repayment of which the government fully guarantees for a maximum term of five years.

OWWA spent an average of 865 million pesos (US $\$ 17$ million) per year from 20022006. Administrative and operating costs comprised 55 percent of expenditures, while the rest was spent on programs and projects.

OWWA officially recognized this problem when its board introduced a cap on operational costs at 50 percent of total expenditures. Operating costs declined, dipping below the 50 percent threshold in 2003 and 2004. However, operational costs increased in the next two years. In 2006, the proportion was 57 percent.

Since 1999, OWWA has brought in more money than it has spent. This surplus is added to OWWA's equity. As a result, OWWA's yearly financial statements show that the fund grew nearly fourfold in 11 years, from 2.2 billion pesos (US $\$ 44$ million) in 1995 to 8.6 billion pesos (US\$172 million) in 2005. To place the magnitude of this amount in the Philippine context, OWWA's total assets are more than twice the 2006 annual budget of its mother agency, DOLE, and 14 times more than the 2006 budget of its sister agency, POEA.

\section{OWWA Services and Benefits}

OWWA members can access a wide range of benefits, including life and disability insurance, loans, education subsidies, training, and other forms of social services and family welfare assistance. Judging from OWWA's budget appropriations in 2006, OWWA poured more resources into some benefits - such as repatriation, other forms of onsite assistance, and insurance - while spending less on others, such as loans, education, and training (see Table 2).

\section{Repatriation Program and Workers Protection}

The repatriation program, which the current OWWA administrator calls the backbone of the agency, facilitates the immediate repatriation of distressed and physically ill contract workers, as well as the remains of those who die while working abroad. In both planned and forced return, OWWA negotiates with employers/brokers and other host-country authorities; facilitates documentary requirements for issuance of exit visas, clearances, monetary claims, and medical or police reports; and coordinates with Philippine embassies and DFA for other necessary administrative actions and airport assistance. Recently, for instance, the government negotiated the release of $700 \mathrm{OFW}$ s jailed in Saudi Arabia, mostly for cultural offenses like carrying a Bible or drinking alcohol. 
OWWA is instructed by law to maintain, among other programs, an Emergency Repatriation Fund to evacuate OFWs in case of wars, disasters, or epidemics. The 1995 act allotted a seed amount of 100 million pesos (US\$2 million) to comply with this law. ${ }^{32}$

During the war in Lebanon in July 2006, for example, OWWA reserved US\$10 million for the evacuation of Filipino workers. ${ }^{33}$ About 6,300 workers were repatriated between July and October 2006, with OWWA eventually spending $\$ 1,200$ per returnee. ${ }^{34}$ It is not clear how many of the repatriated were OWWA members. In 2006, OWWA assisted in the repatriation of 10,834 workers from Lebanon and other countries, spending almost 170 million pesos (US\$3.4 million) on airfare. This represented about 13 percent of revenue in 2006 (see Table 2).

Apart from repatriation, OWWA offers other forms of assistance, services, and programs in its offices abroad, including counseling for distressed workers, paralegal services, and low-key diplomatic initiatives (e.g., negotiations for imprisoned $\mathrm{OFWs}$, mobile welfare services, hospital and prison visits, sports development projects like sport leagues, cultural and recreational activities, and contingency operations during crisis situations). About 600,000 members, or 62 percent of all members in 2006 (both within the Philippines and overseas), received various kinds of assistance or services..$^{35}$

Embassies and consulates abroad provide legal assistance for overseas Filipinos in dis- tress. OLAMWA coordinates all legal assistance services for Filipino migrant workers. The Philippine Congress created a legal assistance fund of 100 million pesos (US\$2 million), partly sourced from OWWA, to pay for foreign lawyers, bail bonds, court fees, and other litigation expenses. ${ }^{36}$

\section{Insurance}

Another expensive item in OWWA's services budget is insurance claims. OWWA provides members with life and personal accident insurance while abroad. The coverage includes 100,000 pesos (US\$2,000) for natural death and 200,000 pesos (US $\$ 4,000$ ) for accidental death; a burial benefit of 20,000 pesos (US\$400) is also provided. OWWA charges an additional 900 pesos (US\$18) per year for health insurance.

As a rider to the life insurance, OWWA also offers monetary assistance to workers who suffer work-related injuries, illness, and disabilities during employment abroad. The benefit ranges from 2,000 pesos (US\$40) to 50,000 pesos (US\$1,000) and up to 100,000 pesos (US\$2,000) in case of permanent disability.

In the past five years, a growing number of OFW s have used the death and disability benefits, from fewer than 600 in 2002 to more than 1,500 in $2006 .{ }^{37}$ Despite this increase, the most current figure is still noticeably small relative to the total membership, and much less relative to the total stock of $\mathrm{OFW}_{\mathrm{s}}$.

According to Roque, many OFWs have private insurance, which may partly explain the 


\begin{tabular}{|c|c|c|c|c|}
\hline Services & $\begin{array}{l}\text { Number of beneficiaries/ } \\
\text { claims/loans/grants }\end{array}$ & Cost & $\begin{array}{l}\text { Cost as a } \\
\text { percentage } \\
\text { of revenue** }\end{array}$ & $\begin{array}{l}\text { Number of beneficiaries/ } \\
\text { claims/loans/grants as a } \\
\text { percentage of total member- } \\
\text { ship*** (except when noted) }\end{array}$ \\
\hline Repatriation & Repatriated 10,834 OFWs & $169,628,508$ & $13.48 \%$ & $1.09 \%$ \\
\hline \multirow[t]{2}{*}{$\begin{array}{l}\text { Workers } \\
\text { assistance* }\end{array}$} & $\begin{array}{l}\text { Assisted 614,697 (local and } \\
\text { overseas) workers at 24/7 } \\
\text { operations center }\end{array}$ & $\begin{array}{l}\text { Data not } \\
\text { available }\end{array}$ & $\begin{array}{l}\text { Data not } \\
\text { available }\end{array}$ & $61.83 \%$ \\
\hline & $\begin{array}{l}\text { Assisted II,759 OFWs at the } \\
\text { Manila airport }\end{array}$ & $\begin{array}{l}\text { Data not } \\
\text { available }\end{array}$ & $\begin{array}{l}\text { Data not } \\
\text { available }\end{array}$ & $1.18 \%$ \\
\hline \multirow[t]{2}{*}{ Insurance } & $\begin{array}{l}\text { Paid I, I22 OFW' claims for } \\
\text { insurance and burial benefits }\end{array}$ & $154,600,000$ & $12.29 \%$ & $0.11 \%$ \\
\hline & $\begin{array}{l}\text { Paid } 395 \text { OFWs' } \\
\text { claims for disability } \\
\text { and dismemberment }\end{array}$ & $9,053,500$ & $0.72 \%$ & $0.04 \%$ \\
\hline \multirow[t]{4}{*}{ Loans } & $\begin{array}{l}\text { Made I37 Predeparture } \\
\text { Loans (PDLs) to OWFs }\end{array}$ & $4,934,768$ & $0.39 \%$ & $0.01 \%$ \\
\hline & $\begin{array}{l}\text { Made } 543 \text { Family Assistance } \\
\text { Loans (FALs) to OFWs }\end{array}$ & $25,383,000$ & $2.02 \%$ & $0.05 \%$ \\
\hline & Made 26I Grocerias loans & $10,500,000$ & $0.83 \%$ & $0.03 \%$ \\
\hline & $\begin{array}{l}\text { Made } 198 \text { loans through } \\
\text { OWWA-National Livelihood } \\
\text { Support Fund Livelihood } \\
\text { Development Program }\end{array}$ & $34,102,000$ & $2.71 \%$ & $0.02 \%$ \\
\hline \multirow[t]{3}{*}{$\begin{array}{l}\text { Education } \\
\text { and training }\end{array}$} & $\begin{array}{l}\text { Maintained } 269 \text { Education for } \\
\text { Development Scholarship } \\
\text { Program (EDSP) grants }\end{array}$ & $16,140,000$ & $1.28 \%$ & $0.03 \%$ \\
\hline & $\begin{array}{l}\text { Made I,98I Skills-for- } \\
\text { Employment Scholarship } \\
\text { Program (SESP) grants }\end{array}$ & $3,040,183$ & $0.24 \%$ & $0.20 \%$ \\
\hline & $\begin{array}{l}\text { Made 2, } 177 \text { Seafarers } \\
\text { Upgrading Program (SUP) } \\
\text { grants }\end{array}$ & $19,071,630$ & $1.52 \%$ & $0.95 \% * * * * *$ \\
\hline \multicolumn{5}{|c|}{$\begin{array}{l}\text { *OWWA's Financial Management System (FMS) does not allow for itemizing the specific services spent on workers } \\
\text { assistance. } \\
\text { **Revenue in } 2006 \text { was } 1,258,010,854 \text { pesos. } \\
\text { *** Total membership as of December } 2006 \text { was } 994,191 \text {. } \\
\text { ****This figure was arrived at by dividing the number of beneficiaries by the total number of deployed seafarers } \\
(230,022) \text { in } 2006 \text {. } \\
\text { Source: Overseas Workers Welfare Administration. }\end{array}$} \\
\hline
\end{tabular}


low number of claims. Former DOLE

Secretary Patricia Santo-Tomas also notes that contract workers are relatively healthier than the general population because of the rigorous medical examinations required before leaving. ${ }^{38}$ Further, the insurance benefits are "one size fits all," and the lump-sum benefits are low relative to $\mathrm{OFW}$ earnings.

\section{Loan Products}

To prevent illegal recruiters and loan sharks from preying on overseas workers and their families, OWWA, in coordination with government financial institutions, is mandated by law to extend loans to overseas workers. OWWA offers three kinds of loans:

1. Predeparture loans (PDL) are offered to help defray the cost of predeparture requirements, including medical examinations, subsistence allowance, clothing, and pocket money.

2. Family assistance loans (FAL) are for emergency purposes or family needs. The maximum loan amount is set at 40,000 pesos (US\$800), payable in six months to a year and with a 9 percent annual interest deducted in advance. This benefit is limited to members who have at least six months remaining in their employment contract.

3. Livelihood loans are offered to improve access to entrepreneurial development opportunities upon return. In a joint undertaking with the National Livelihood Support Fund (NLSF), the OWWA-NLSF Livelihood Development Program offers collateral-based loans of up to 200,000 pesos (US\$4,000) per qualified borrower at a 9 percent annual interest rate.

Partnerships with five or fewer members are entitled to a maximum loan of 1 million pesos (US\$20,000) with 200,000 pesos (US\$4,000) for each member. Borrowers with no collateral can obtain loans of up to 50,000 pesos (US\$1,000). In 2004, OWWA started the Groceria Project, an interest-free, loan-assistance package extended in the form of goods worth 50,000 pesos (US\$1,000) per qualified groups of OFWs and their families.

One recurring problem with all these loan programs has been low repayment rates. PDL and FAL loans have a repayment rate of 29 percent. Indeed, only 137 PDLs and 543 FALs One recurring problem with all these loan programs has been low repayment rates. were approved in 2006 before OWWA suspended lending pending further evaluation. ${ }^{39}$

Similarly, as early as the late 1980s, OWWA introduced livelihood lending programs without much success. For instance, although the first livelihood program introduced in 1987 generated employment for about 3,600 workers, it suffered from very low repayment rates and was suspended by 1995. A year later, the same program was repackaged, this time with a higher loan ceiling and entrepreneurship training. Like its predecessor, this program, which funded over 430 enterprises in eight years, was plagued by repayment problems and was eventually replaced in 2004 by the OWWA-NLSF Livelihood Development 
Program mentioned above..$^{40}$ In 2006, OWWA-NLSF funded 198 projects costing 34 million pesos (US\$680,000).

Reasons behind the low repayment rates are not clear since the government has not evaluated many of these programs. Administrator Roque, some nongovernmental organization (NGO) leaders, and the media have surmised that overseas workers sometimes perceive the loan programs as dole-outs rather than subsidized loans, resulting in low repayment rates. ${ }^{41}$

\section{Scholarships and Trainings}

OWWA also provides four kinds of scholarship grants and training opportunities for members and, in some cases, their dependents. The Education for Development Scholarship Program (EDSP) provides grants of 60,000 pesos (US\$1,200) per year to deserving and qualified dependents attending college-degree courses with curriculums of five years or less. The Skills-forEmployment Scholarship Program (SESP) pays for one-year technical and six-month vocational courses reflecting the technical skill requirements of overseas jobs.

A separate program caters to seafarers. The Seafarer's Upgrading Program (SUP) aims to develop the expertise of Filipino seafarers in accordance with technological advancements and international maritime standards. Financial assistance ranges from 1,200 pesos (US\$24) to 7,500 pesos (US\$150) per course.

In partnership with Microsoft Philippines, the Tulay (Bridge) Education Program offers training and access to computer technology so that families can communicate through the Internet. Tulay takes part in Microsoft's Unlimited Potential (UP), a global initiative aimed at providing technology and skills for underserved individuals. Aside from Internet and e-mail use, OWWA members and their families living near Community Technology Learning Centers (CTLC) can also take courses in basic computer applications, such as Word, PowerPoint, and Excel.

Mandatory predeparture orientation seminars (PDOS) help build skill sets and familiarize would-be migrants with the culture and practices of their host countries. Specific modules are customized for household workers, performing artists and entertainers, nurses, and seafarers, as well as for workers migrating to certain countries/regions, such as Hong Kong, Libya, the Middle East, South Korea, and Taiwan. In conducting these seminars, OWWA partners with members of the private sector (e.g., recruitment agencies and associations) and civil society (e.g., workers' groups and NGOs). The partners conduct the orientations while OWWA prepares the materials, sets standard qualifications, and conducts training for trainers. ${ }^{42}$ A 2005 survey conducted by the Scalabrini Migration Center found that 84 percent of respondents considered PDOS "useful" or "very useful," particularly for first timers. However, the survey revealed the need for more country-specific information and smaller group discussions. ${ }^{43}$

Apart from PDOS, few OFWs benefit from scholarships and training-related programs. For instance, only 0.95 percent of seafarers 
deployed in 2006 availed themselves of SUP while the 1,981 SESP scholars represented about 0.2 percent of total membership (see Table 2 on page 16). Unlike the other programs, EDSP is competitive and highly selective. In 2005, about 2,500 dependents applied for 100 spots. An additional 45 spots are made available to students pursuing courses in priority fields in science and technology, such as engineering and science teaching.

\section{Protecting Temporary Workers: Lessons and Cautions from the Philippines}

In cash-strapped developing countries, operating a welfare fund that migrants or their employers finance offers a potentially efficient and feasible solution to sharing the cost of protection. However, the Philippine experience shows the challenges involved in making a welfare fund work. A welfare fund has to (1) find the right balance of services, (2) create meaningful partnerships, (3) build strong state capacity, and (4) actively involve destination countries.

\section{Balance Core and Secondary Services}

A welfare fund's services can be grouped into two broad categories. Core services, those that protect migrant workers from the risks they face while abroad, include repatriation in case of breakdowns in public order, such as war, or in case of other forms of maltreatment; health and life insurance; and legal assistance for settling work-related disputes and frauds. Secondary services help migrant workers, before and after departure, and the families left behind. These include education and training, reintegration programs (e.g., livelihood loans), and predeparture loans.

A fund's resources may be adequate to provide core services, since a relatively small proportion of migrant workers actually experience the most severe problems while working abroad. However, a fund cannot deliver costly secondary services on its own based on a small membership fee, as OWWA's experience demonstrates. Ding Bagasao, a prominent Filipino NGO leader and academic, has asked, "Why is OWWA not asking for more than US\$25?" $\$ 4$

It is not surprising that, despite the rhetoric, OWWA has actually extended secondary services to relatively few OFWs and their families — in most cases meeting only the minimum requirements mandated by law. Offering secondary services to few beneficiaries only creates undue expectations and dissatisfaction among fund members as well as the general public. Welfare funds should focus not only on critical services, but also those that can be delivered in an effective manner and meaningful scale. OWWA illustrates that countries need to find the right balance of what aspects of welfare the government
OWWA illustrates that countries need to find the right balance of what aspects of welfare the government can truly deliver, and they need to search for partners in delivering services. 
can truly deliver, and they need to search for partners in delivering services.

\section{Create Meaningful Partnerships}

Since private and public institutions can also provide secondary services, welfare funds should delegate these services to such institutions. Partnerships can range from sharing responsibilities to full outsourcing in order to supplement direct capacity.

OWWA has started to take such steps. It outsourced medical insurance to the Philippine Health Insurance Corporation (PHILHEALTH) in 2003 and partnered with NLSF in giving out livelihood loans. It has also outsourced the majority of PDOS to NGOs and members of the private sector. In 2006, OWWA provided a very small portion of PDOS with consultants responsible for the large majority (see Table 2).

Even in core services, such as repatriation and insurance, partnerships have been and will be critical to more efficient delivery. For instance, OWWA partnered with the International Organization for Migration (IOM) in the repatriation of OFWs from the recent war in Lebanon. IOM repatriated almost 67 percent of Filipino returnees. ${ }^{45}$ On top of that, OWWA was able to decrease its own repatriation costs by using IOM's discount on airfares. ${ }^{46}$

Civil-society organizations, when welfare funds properly engage them, can also play many roles, such as providing services with government help, giving inputs in the policy- making process, and assuming critical oversight functions to address accountability and corruption issues. A welfare fund should explore new mechanisms to build partnerships with civil society. In the Philippines, for instance, organizations like Unlad Kabayan and the Economic Resource Center for Overseas Filipinos (ERCOF) promote social entrepreneurship among returning OFWs and provide services for enterprise development in the Philippines.

Organizations like these can offer critical human resources that can effectively provide the secondary services of a welfare fund.

Apart from partnerships with civil society and the private sector, coordination with other government agencies and local governments can be critical. For example, OWWA recently signed a memorandum of agreement with the governor of Nueva Vizcaya to establish a migrants' desk in the province. OWWA will train local government personnel in programs and projects relevant to migrant workers and their families. ${ }^{47}$

However, partnerships also come with risks, such as poor coordination on resource issues and misunderstandings about expectations. Therefore, welfare funds should enter partnerships with caution. Public-private partnerships must be based on solid understandings of the respective responsibilities, agreed indicators of success, and complete transparency. Otherwise, partnerships may fail and even deplete a fund's balance, which is critical to its continued financial stability. 
Although they can potentially augment the state's capacity to deliver services, effective partnerships also require a certain degree of preexisting capacity. In working with partners, governments must have the flexibility to address different needs and expectations of private and nongovernmental organizations, which tend to work on different timetables and have different notions of accountability. The inflexibility of government bureaucracy can present a major challenge in creating effective partnerships. Despite the risks, exploring new partnerships is worthwhile, particularly because it provides reform choices and allows more room for innovative and unconventional thinking.

\section{Build State Capacity}

Questions about what a welfare fund can and cannot do naturally lead to the critical issue of state capacity. The role of the state, in both the developed and developing world, has changed in many ways, in part as a response to greater economic integration. In many countries, however, particularly in the developing world, the state has yet to develop the capacity to respond to these changes adequately. The OWWA experience has shown that strong state capacity allows the country to make use of opportunities that labor migration provides and to protect and promote the interests of temporary workers.

Therefore, developing countries need to adopt frameworks and tools that permit (1) representation and meaningful participation of migrant workers; (2) political, administra- tive, and financial transparency and accountability; and (3) the effective use of government employees.

\section{Migrant Workers' Representation and Participation}

In any welfare fund, it is especially important to strengthen capacities for policy formulation and coordination. A fund should include a wide array of stakeholders, particularly the members themselves. One of the unique aspects of the Philippine case is the dispersal of its estimated 3.8 million temporary workers. Representing their interests and directing the OWWA welfare fund remain major challenges. Although migrants are represented on the OWWA board, they constitute a very small minority.
Further, OWWA does not have a mechanism for voting on major issues or even electing its board members. As already noted, the Philippine president appoints all board members. setup, given the logistical difficulty of consulting a membership dispersed in over 190 countries, this still raises questions of to whom OWWA should be accountable. The Philippine Congress is considering a bill that would change OFW representation on the OWWA board. However, since similar bills filed in the previous Congress lacked sup- 
port, this bill's prospect of turning into law remains $\operatorname{dim}^{48}$

Welfare funds need to consult extensively with different stakeholders, especially the migrants, to find solutions for addressing this type of problem. Possible solutions can range from the simple, such as requiring appointees to be former or current migrants, to the more complex, such as having fund members periodically elect migrant representatives.

Apart from increasing the number of migrant board representatives, it is also important for welfare funds to create clear avenues or mechanisms that allow for regular consultation with all fund members. Without such avenues, the extent to which these migrant board members can truly represent all migrants will always be limited. A method of canvassing the needs of migrants and an evaluation system of program performance need to be developed to ensure that welfare funds are effectively used. For instance, OWWA's plan to facilitate and support the creation of an umbrella of OFW organizations overseas is a step in this direction. ${ }^{49}$

\section{Transparency and Accountability}

Representation of migrants' interests raises questions of transparency in the management and accounting of the welfare fund, a quality critical to a fund's successful operation. The government running a welfare fund should create mechanisms for periodically informing fund members about the fund's financial standing and the services offered in a given period, and it should provide a way for mem- bers to effectively communicate with the fund's board.

Operational transparency is even more critical in instances where a fund is accused of corruption and mismanagement of funds. From 1999 to 2005, the Philippine Commission on Audit's reports on OWWA highlighted millions of pesos in unrecoverable or "doubtful accounts," and nonliquidated cash advances. The largest of these unredeemable investments was the Smokey Mountain Project, a housing development program for the urban poor. In 2005, government auditors noted that the recovery of the 479 million peso (US\$9.6 million) investment in the project is "uncertain."

Without operational transparency, speculation about the welfare fund's financial standing can surface and damage the credibility of fund managers. For instance, during the 2006 war in Lebanon, the Philippine media reported allegations that OWWA did not have the resources available to fund repatriation efforts although the agency's audited accounts clearly indicated otherwise.

At the same time, the board's process for making policy decisions also should be transparent. For example, OWWA members and the general public cannot access board meeting minutes. This practice has resulted in a veil of suspicion. In 2003, OWWA's decision to outsource medical insurance to the Philippine Health Insurance Corporation (PHILHEALTH), the national government's insurance company, caused a scandal 
because some members of migrant and civilsociety groups interpreted the transfer as a "bail out" of the ailing corporation. A resolution filed in the Philippine Congress noted the "dissatisfaction of OFWs" and charged that the "majority of the OWWA board members and officials shunned the lone OFW representative who has consistently objected to the transfer." ${ }^{51}$ The outsourcing to PHILHEALTH was also reportedly linked to the 2004 presidential campaign. Some migrant groups alleged that the diversion of OWWA funds enabled President Gloria Arroyo to give away PHILHEALTH insurance cards during the campaign period. ${ }^{52}$ Whether there is substance to these allegations is difficult to ascertain due to the lack of transparency in the board's decisionmaking process.

\section{Effective Use of Government Employees}

Another central component of state capacity is the effective use of government employees. Welfare funds should explore approaches that tackle civil-service pay, management structures, career structures, and training.

OWWA has allocated more than half of its annual budget to operational expenses, with about 40 percent going to salaries and other personnel benefits. Some members of civil society have criticized the high operational costs. The international nature of OWWA's operations partly explains its expenses. Although this pattern of spending can be justifiable, welfare funds should still assess whether such spending contributes to human resources that benefit migrants.

\section{Involve Destination Countries}

Legal protection of migrants is challenging, especially in destination societies with value systems and worldviews that differ from those in the origin country. For instance, the majority of the Philippines' welfare officers are located in the Middle East, partly due to the high number of welfare cases in this region. ${ }^{53}$ However, protection of overseas workers should also concern destination countries.

Toward this end, countries of destination should consider providing technical and financial assistance in capacity-building projects. They also should consider developing mechanisms to protect the welfare of temporary workers by signing bilateral agreements or memorandums of understanding (MOUs) with countries of origin that explicitly address workers' protection. Although the Philippines has signed 12 bilateral agreements with destination countries, these MOUs and agreements are merely generalities and guidelines on migrant workers; they do not give bases for enforcing compliance on wages and other terms of employment. ${ }^{54}$

Given that migrant workers provide services critical to the economies of receiving countries, it may be logical and useful for destination countries to give them necessary protection in employment-related matters, such as wages, working hours, contract compliance, and occupational safety. Destination countries can conduct studies or audits of their own national laws to identify and perhaps codify legislation, legal precedents, and practices that may already exist. Bilateral or 
regional agreements could go a step further and make it mandatory for a given destination country to provide such legal protection. No major country of destination has ratified the UN Treaty on the Protection of Migrant Workers and their Families. Consequently, destination countries' national laws remain the best way to enforce and internalize migrant-worker protection. ${ }^{55}$

Since this type of protection is a transnational issue that requires transnational solutions, partnerships across borders are critical. Institutions like OWWA have limited powers because they cannot interfere directly with domestic issues in destination countries. Governments of the destination countries can
Since this type of protection is a

transnational issue that requires transnational solutions, partnerships across borders are critical. complement the offerings of welfare funds. For example, the European Commission developed a policy document arguing the merits of "global mobility partnerships" with third-country nationals. One of the suggested commitments that EU Member States and/or the EC could give is the provision of "predeparture linguistic or technical training for persons with a concrete employment prospective abroad. ${ }^{956}$

\section{Conclusion}

Protecting overseas workers will gain more attention as temporary migration continues to grow worldwide. Since 1997, temporary migration to countries that belong to the Organization for Economic Cooperation and Development (OECD) has grown annually by 9 percent. The number of temporary migrants in East and West Asia, including Saudi Arabia and the United Arab Emirates, has consistently grown by 2.5 percent per year since 1985. In the United States, growth in temporary migration averaged 10.4 percent per year, from 208,100 entries in 1997 to 396,700 in $2004 .^{57}$

Temporary migration presents countries of origin with the dilemma of ensuring the protection of their workers abroad. This Insight provides an overview of the Philippine government's approach to protection and the benefits and limitations of its main protection vehicle, OWWA. The Philippine experience shows that the protection of overseas workers can be institutionalized through three elements: (1) a mechanism for repatriation, (2) provision of insurance and loans, and (3) education and training.

This strategy provides key lessons for origin and destination countries that are thinking more seriously about protecting temporary overseas workers. A membership-driven welfare fund like OWWA can benefit migrants in a number of ways. First, it allows the government to raise sufficient revenue to finance 
inherently expensive needs of migrants in destination countries. Without private funding from overseas workers, cash-strapped governments like the Philippines would be hard pressed to allocate sufficient resources from the national budget. Second, a welfare fund also enables a government to provide critical on-site services, especially repatriation, in emergency situations. Finally, a welfare fund, if managed effectively, has the potential to financially support activities that can leverage migrant resources for development, such as business entrepreneurship and career development among returning migrants.

However, countries of origin must overcome several limitations if they want to realize these benefits. The Philippine case shows the importance of tailoring services to the immediate or core needs of overseas workers without overextending the government's capacity. Given that many OFWs work in conflict-prone regions, it makes sense that the Philippines' top priority has been building up the contingency fund for repatriation. Other sending countries may and should have different priorities. For instance, Mexico and Morocco might focus less on large-scale repatriation and more on wages, labor conditions, and secondary services.

Governments should evaluate where the capacity to deliver services lies. Some countries of origin face limited state capacity, which can be addressed through wellmanaged partnerships between governments and with private and nongovernmen- tal organizations. These countries can enlist private organizations to deliver programs to overseas workers.

Welfare funds require effective institutions that allow for transparency as well as a way to represent the views of the dues-paying members themselves. This guarantees that services remain relevant to the needs of beneficiaries. It is a challenge to design a useful way to consult the beneficiaries, given that migrants are typically dispersed to many countries.

In addition, countries of origin should not be the only ones expected to protect migrant workers. Destination countries also need to do their part in protecting migrant workers within their boundaries.

In the Philippines, where one in 12 people is a migrant and where everyone has a relationship to migration in one way or another, managing institutions like OWWA can be inherently difficult. ${ }^{58}$ OWWA serves a population of 3.8 million, highly mobile temporary workers scattered in over 190 countries, as well as the families left behind - an enormous task that few governments have even attempted systematically. Its experience provides a rich set of lessons and cautions about what is involved in protecting overseas workers. Once its limitations are addressed, OWWA can be a useful template for many developing countries as they face the mounting challenges of protecting workers abroad. 


\section{Acknowledgements}

The authors gratefully acknowledge the thoughtful comments of MPI's Kathleen Newland; the editorial contributions of Kirin Kalia; the technical support of April Siruno, Aaron Terrazas, and Velma Fan; the research assistance of Laiden Pedrina of the University of the Philippines; and the support of the Brookings Institution, Global Economy and Development Program. They give special thanks to OWWA Administrator Marianito Roque and his staff for providing access to OWWA's resources and data, and to Patricia Santo-Tomas, Ildefonso Bagasao, Arturo Brion, Gregorio Oca, Florenda Herrera, Francis Oca, Jeremiah Opiniano, and Frencel Tingga for sharing their time and expertise. This Insight is made possible by the generous support of the John D. and Catherine T. MacArthur Foundation and by a grant from the Multilateral Investment Fund of the Inter-American Development Bank.

\section{ENDNOTES}

1. Migrant-sending refers to a country that has a large-scale government program for facilitating the export of its labor force.

2. Neil G. Ruiz, "Emigration and Higher Education in the Philippines," Paper presented at the Labor and Employment Association Conference, Chicago, IL, January 7, 2007.

3. Philippine Overseas Employment Administration, "Global Presences: A Compendium of Overseas Employment Statistics 2006" (Mandaluyong City: POEA, 1996), 51-52.

4. Overseas Filipino Workers $(\mathrm{OFWs})$ is the official term used by the Philippine government to refer to Filipinos abroad working on finite or temporary contracts.

5. Asian Development Bank, Enhancing the Efficiency of Overseas Filipino Workers'Remittances (Manila: Asian Development Bank, 2004), 61.

6. Florian A. Alburo and Danila I. Abella, "Skilled Labour Migration from Developing Countries: Study on the Philippines," International Migration Papers, Paper 51 (Geneva: International Labour Office, 2002), 16.

7. Philippine Overseas Employment Administration, Global Presences, 52.

8. Ruth C. Gonzaga, “Overseas Filipino Workers (OFWs) Remittances: Compilation Practices And Future Challenges," Paper presented at the Conference of the International Association for Official Statistics (IAOS), 2006.

9. Michelle V. Remo, “Cost of Sending Remittances to RP Going Down, Says BSP," Philippine Daily Inquirer, June 7, 2007.

10. See note 7 above.

11. Jorge Villamor Tigno, "Governance and Public Policy in the Philippines: RA 8042 and the Deregulation of the Overseas Employment Sector" (PhD dissertation, University of the Philippines-Diliman, 2003), 114-115.

12. Graziano Battistella, "Return Migration in the Philippines: Issues and Policies," in International Migration: Prospects and Policies in a Global Market, ed, Douglas Massey and Edward Taylor (Oxford: Oxford University Press, 2004), 232.

13. Anne-Marie Hilsdon, "The Contemplacion Fiasco: The Hanging of a Filipino Domestic Worker in Singapore," in Human Rights and Gender Politics, ed. Anne-Marie Hilsdon, Martha Macintyre, Vera Mackie and Maila Stivens (New York: Routledge, 2000), 172-173.

14. US Department of State, "1995 Patterns of Global Terrorism," Office of the Coordinator for Counterterrorism, http://www.fas.org/irp/threat/terror 95/terasi.htm.

15. Joaquin Gonzales III, Philippine Labour Migration: Critical Dimensions of Public Policy (Singapore: Institute of Southeast Asian Studies, 1998), 6-7.

16. See note 15 above. 
17. Michael A. Bengwayan, "When Filipino maids return home in coffins," New Straits Times, March 7, 2001.

18. See note 17 above.

19. Robyn Rodriguez, "Domestic Insecurities: Female Migration from the Philippines, Development and National

Subject-Status," in UCSD Center for Comparative Immigration Studies Working Paper Series (La Jolla: UCSD Center for Comparative Immigration Studies Working Paper 115, 2005), 7.

20. Author emphasis.

21. Philippine House of Representatives, Republic Act 8042, Migrant Workers and Overseas Filipinos Act of 1995.

22. Edgar Rodriguez and Susan Horton, "International Return Migration and Remittances in the Philippines," in University of Toronto Department of Economics Working Paper Series (Toronto: University of Toronto Department of Economics, 1995), 18.

23. Overseas Workers Welfare Administration, Board of Trustees, http://www.owwa.gov.ph/page/board_of_trustees/.

24. The staff numbers are estimates; actual numbers are unknown according to OWWA.

25. Section 23 of the Rights and Enforcement Mechanism Under International and Regional Human Rights System of the Philippine Department of Foreign Affairs, as cited by Arnel F. de Guzman, "A Critical Assessment of the Migrant Workers and Overseas Filipinos Act of 1995 (RA 8042)," unpublished paper, 9-10.

26. Overseas Workers Welfare Administration, Omnibus Policies, Board Resolution No. 138, 2003, http://www.owwa.gov.ph/filemanager/download/.

27. Maruja Asis, Preparing to Work Abroad: Filipino Migrants' Experience Prior to Deployment (Manila: Philippine Migrants Rights Watch and Friedrich Ebert Stiftung, 2005), 52.

28. Marianito Roque, interview by authors, June 1, 2007.

29. Exchange rate used: 50 Philippine pesos to 1 US dollar.

30. See note 28 above.

31. Philippine Commission on Audit, 2005 Annual Audited Report of OWWA.

32. See note 21 above.

33. "Few Pinoys in Lebanon Want to Go," Manila Standard, August 24, 2006.

34. Overseas Workers Welfare Administration, Annual Report 2006, 27.

35. Note that members who used the workers assistance program might also be accounted for in other services, such as repatriation. Given the limitations of OWWA data, it is difficult to verify this assumption.

36. Renee E. Ofreneo and Isabelo A. Samonte, "Empowering Filipino Migrant Workers: Policy Issues and Challenges," in International Migration Papers (Geneva: International Labour Organization, 2005), 8-12.

37. Overseas Workers Welfare Administration, Insurance and Health Care Availment Report, 2002-2006.

38. Patricia Santo-Tomas, interview by authors, May 24, 2007.

39. See note 28 above.

40. Masami Ochi, "Return Migration of Filipina Overseas Workers: Some Implications for Reintegration Programmes," Typescript 2005.

41. Marianito Roque, see note 28; Candice Y. Cerezo, "Failures Bared in Government Lending Project for OFW Groups," Manila Times, January 3, 2007.

42. A.K. Masud Ali, "Predeparture Orientation Programme, Study of Good Practices in Asia, A Comparative Study of Bangladesh, the Philippines and Sri Lanka," in Labour Migration in Asia: Protection of Migrant Workers, Support Services and Enhancing Development Benefits, ed. Caroline Mackenzie (Geneva: IOM, 2004), 109.

43. Maruja Asis, Preparing to Work Abroad: Filipino Migrants' Experience Prior to Deployment, 7-10.

44. Ding Bagasao, interview by authors, June 5, 2007.

45. Overseas Workers Welfare Administration, Annual Report 2006, 28.

46. See note 38 above.

47. Philippine Information Agency, "OWWA to Establish Migrants' Desk in Nueva Vizcaya," October 16, 2006.

48. Philippine House of Representatives, House Bill No. 00699 An Act Providing for the Selection of Additional Memberships in the Boards of the POEA and the OWWA, Amending for Such Purpose Republic Act 8042, Otherwise Known as the Migrant Workers and Overseas Filipinos Act of 1995. Introduced by Congressman Rexlon Gatchalian; Philippine House of Representatives, House Bill No. 1357 An Act to Provide for an OWWA Charter to Govern the 
Operation and Administration of the Overseas Workers Welfare Administration, Prescribe for Public Accountability on the OWWA Administrators and Officials Thereof and for Other Purposes Introduced by Rep. Roseller L. Barinaga. 49. See note 28 above.

50. Philippine Commission on Audit, Annual Audited Report of OWWA, 1999, 2000, 2001, 2002, 2003, 2004, and 2005. Available at: http://www.coa.gov.ph/Financial_Reports.htm.

51. Philippine House of Representatives, House Resolution No. 03 Resolution on Her Excellency President Gloria Macapagal-Arroyo to Immediately Recall Executive Order (EO) No. 182 dated 14 February, 2003 Which Allowed the Transfer of the OFW Medicare Fund Under the Charge and Care of Overseas Workers Welfare Administration (OWWA) to the Philippine Health Insurance Corporation (PHILHEALTH). Introduced by Rep. Roseller Barinaga. 52. Alecks P. Pabico, “The Truth About OWWA Funds," Inside PCIJ: The Stories Behind Our Stories, August 1, 2006, http://www.pcij.org/blog/?p=1091.

53. See note 38 above.

54. Stella P. Go, "Recent Trends in International Movements and Policies: The Philippines," Paper prepared for the Workshop on International Migration and Labour Markets in Asia, February 17, 2006, Japan Institute for Labour Policy and Training (JILPT), Tokyo, Japan, 5-6.

55. See note 44 above.

56. European Commission, "Circular Migration and Mobility Partnerships between the European Union and Third Countries," Communication 2007, 6.

57. Dovelyn Rannveig Agunias, "Linking Temporary Worker Schemes with Development," Migration Information Source, February 2007, http://www.migrationinformation.org/Feature/display.cfm?id=576.

58. Marianito Roque, interview by authors, October 13, 2006.

\section{List of Acronyms}

Bureau of Employment Services (BES)

Commission on Audit (COA)

Commission on Filipinos Overseas (CFO)

Department of Foreign Affairs (DFA)

Department of Labor and Employment (DOLE)

Economic Resource Center for Overseas Filipinos (ERCOF)

Education for Development Scholarship Program (EDSP)

Family Assistance Loans (FAL)

International Organization for Migration (IOM)

Mandatory Predeparture Orientation Seminars (PDOS)

National Livelihood Support Fund (NLSF)

National Seamen Board (NSB)

Office of the Legal Assistant for Migrant

Workers Affairs (OLAMWA)
OFW Family Circle (OFC)

Organization for Economic Cooperation and Development (OECD)

Overseas Employment Development Board (OEDB)

Overseas Filipino Workers (OFWs)

Overseas Workers Welfare Administration (OWWA)

Philippine Health Insurance Corporation (PHILHEALTH)

Philippine Overseas Employment Administration (POEA)

Predeparture Loans (PDLs)

Seafarer's Upgrading Program (SUP)

Skills-for-Employment Scholarship Program (SESP)

Welfare Fund Administration (WFA) 


\section{Appendix I. Detailed Descriptions of Occupation Types Abroad}

\begin{tabular}{|c|c|c|}
\hline Type & Broad Category & Specific Occupations \\
\hline Type I & $\begin{array}{l}\text { Professional, technical, } \\
\text { and related workers } \\
\text { (includes entertainers) }\end{array}$ & $\begin{array}{l}\text { - Medical, dental, veterinary, and related workers } \\
\text { - Aircraft and ship officers } \\
\text { - Architects, engineers and related technicians } \\
\text { - Composers and performing artists } \\
\text { - Sculptors, painters, photographers, and related } \\
\text { creative artists } \\
\text { - Teachers (including supervisors and principals) } \\
\text { - Mathematicians, statisticians, system analysts, and } \\
\text { related workers } \\
\text { - Other }\end{array}$ \\
\hline Type 2 & $\begin{array}{l}\text { Managerial, executive, and } \\
\text { administrative workers } \\
\text { Sales workers } \\
\text { Agricultural, animal } \\
\text { husbandry, and forestry } \\
\text { workers, and fisherman }\end{array}$ & $\begin{array}{l}\text { - same as broad category } \\
\text { - Salesmen, shop assistants, and related workers } \\
\text { - Sales supervisors and buyers } \\
\text { - Others } \\
\text { - Agricultural and animal husbandry workers, } \\
\text { fishermen, hunters, and related workers } \\
\text { - Others }\end{array}$ \\
\hline Type 3 & Clerical workers & $\begin{array}{l}\text { - Clerical and related workers } \\
\text { - Bookkeepers, cashiers, and related workers } \\
\text { - Computing machine operators } \\
\text { - Telephone and telegraph operators } \\
\text { - Secretaries, stenographers, typists, and card/tape- } \\
\text { punching machine operators } \\
\text { - Other }\end{array}$ \\
\hline Type 4 & Service workers & $\begin{array}{l}\text { - Helpers and related housekeeping service workers } \\
\text { - Cooks, waiters, bartenders, and related workers } \\
\text { - Building caretakers, cleaners, and related workers } \\
\text { - Service workers } \\
\text { - Hairdressers, barbers, beauticians, and related } \\
\text { workers } \\
\text { - Protective service workers } \\
\text { - Others }\end{array}$ \\
\hline
\end{tabular}


Appendix I. Detailed Descriptions of Occupation Types Abroad (Continued)

\begin{tabular}{|c|c|c|}
\hline Type & Broad Category & Specific Occupations \\
\hline Type 5 & $\begin{array}{l}\text { Production process } \\
\text { workers, transport } \\
\text { equipment operators, } \\
\text { and laborers }\end{array}$ & $\begin{array}{l}\text { - Transport equipment operators } \\
\text { - Bricklayers, carpenters, and other construction } \\
\text { - Electrical fitters and related electrical and electron- } \\
\text { ics workers } \\
\text { - Plumbers, welders, sheet-metal, and structural metal } \\
\text { preparers and erectors } \\
\text { - Machinery fitters, machine assemblers, and preci- } \\
\text { sion-instrument makers } \\
\text { - Laborers } \\
\text { - Tailors, dressmakers, sewers, upholsterers, and } \\
\text { related workers } \\
\text { - Material-handling and related equipment operators } \\
\text { - Painters } \\
\text { - Production and related workers } \\
\text { - Production supervisors and general foremen } \\
\text { - Blacksmiths, toolmakers, and machine-tool opera- } \\
\text { tors } \\
\text { - Food and beverages processors } \\
\text { - Furniture makers and related workers } \\
\text { - Stationary engine and related equipment operators }\end{array}$ \\
\hline
\end{tabular}




\section{About the Authors}

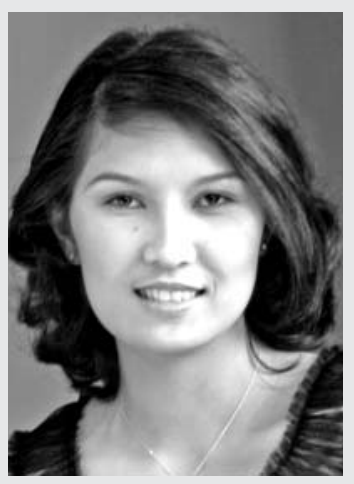

\section{Dovelyn Rannveig Agunias}

Dovelyn Rannveig Agunias is an Associate Policy Analyst for the Migration Policy Institute's Migrants, Migration, and Development Program. Ms. Agunias focuses on remittances, Diasporas worldwide, and the migration-development nexus. She recently co-authored an MPI Policy Brief, "Circular Migration and Development: Trends, Policy Routes, and Ways Forward," and authored two MPI reports: "Remittances and Development: Trends, Impacts and Policy Options - A Review of the Literature" and "From Zero-Sum to a Win-Win Scenario: A Literature Review of Circular Migration.” Before joining MPI, Ms. Agunias was an Edward Weintal Scholar at the Institute for the Study of Diplomacy. She holds a MS in foreign service, with honors, from Georgetown University and a BA in political science from the University of the Philippines.

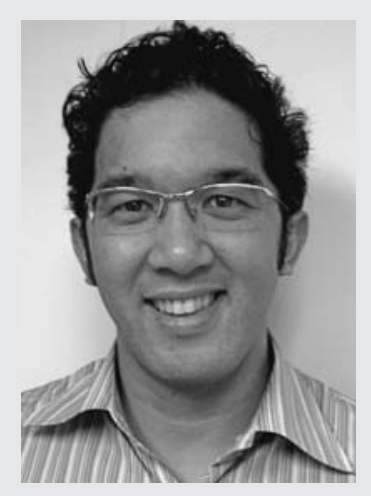

\section{Neil G. Ruiz}

Neil G. Ruiz is a Research Fellow for the Brookings Institution's Global Economy and Development Program and a $\mathrm{PhD}$ candidate in political science at the Massachusetts Institute of Technology. He specializes in comparative and international political economy, global labor markets, migration policy, the relationship between international migration and economic development, and Southeast Asian politics. Mr. Ruiz has several years of experience in policy analysis and development work as a consultant for the Asian

Development Bank and the Migration Policy Institute. His dissertation, titled "Made for Export: Labor Migration, State Power, and Higher Education in a Developing Society," proposes a theory for why developing countries create policies for exporting labor. Mr. Ruiz earned his MSc in economic history from Oxford University and graduated Phi Beta Kappa and High Honors from the University of California, Berkeley with a BA in political science. 
The Migration Policy Institute (MPI) is an independent, nonpartisan, nonprofit think tank dedicated to the study of the movement of people worldwide. The institute provides analysis, development, and evaluation of migration and refugee policies at the local, national, and international levels. It aims to meet the rising demand for pragmatic responses to the challenges and opportunities that migration presents in an ever more integrated world. MPI produces the Migration Information Source at www.migrationinformation.org.
This Insight is part of a series from MPl's Program on Migrants, Migration, and Development. Previous program publications include:

- "Leveraging Remittances for Development" by Dilip Ratha, June 2007.

- "The Phenomenal Rise in Remittances to India: A Closer Look" by Muzaffar A. Chishti, May 2007.

- "Circular Migration and Development:Trends, Policy Routes, and Ways Forward" by Dovelyn Rannveig Agunias and Kathleen Newland, April 2007.

- "Remittances and Development:Trends, Impacts, and Policy Options-A Review of the Literature" by Dovelyn Rannveig Agunias, September 2006.

- "From Zero-Sum to a Win-Win Scenario: A Literature Review on Circular Migration" by Dovelyn Rannveig Agunias, September 2006.

The Migration Information Source, MPI's award-winning online journal, featured a Special Issue on Migration and Development in February 2007. It is available at http://www.migrationinformation.org/development.cfm.

MPl's work on Migrants, Migration, and Development is made possible by the generous support of the John D. and Catherine T. MacArthur Foundation and by a grant from the Multilateral Investment Fund of the Inter-American Development Bank.

\section{w w w. mig ration policy.org}

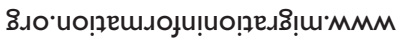

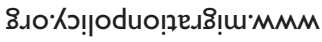

$\left(\mathrm{xRf}^{\prime} 006 \mathrm{I} 99 \mathrm{Z} \mathrm{Z0Z}\right.$ $0+61992702$

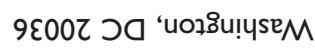
00ع әə!!ns MN 7әә.7ร प79| 00†। 